\title{
In memory of Jerry Simpson 1939-2020
}

\author{
Chris I. de Zeeuw ${ }^{1}$, Robert A. Hensbroek ${ }^{2^{*}}$, Jun Maruta ${ }^{3}$ and Jan Voogd ${ }^{1}$
}

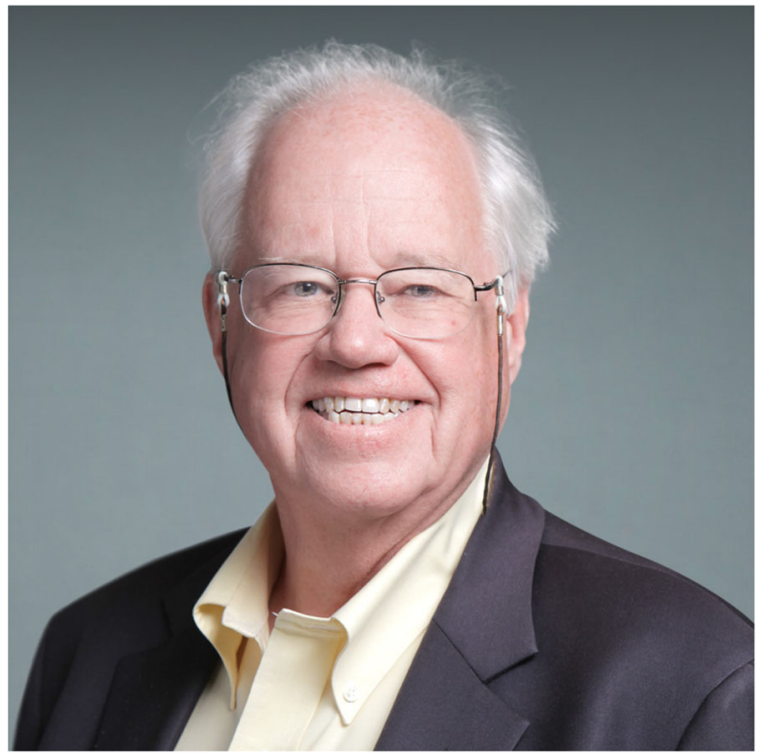

It saddens us to announce the death of John "Jerry" I. Simpson (80), Professor Emeritus at the Department of Neuroscience and Physiology, NYU Langone Health, in New York. He passed away quietly on March 22nd after having been continually hospitalized for 3 months. Jerry is survived by his wife Diane.

Jerry was well known in the cerebellar community for his intellect, his encyclopedic knowledge, his outgoing personality and wit, his entertaining lectures sprinkled with humor, and his thought-provoking questions.

After getting his Ph.D. at MIT, he started in the cerebellar field as a postdoc with Masao Ito at the University of Tokyo. Subsequently, he was a postdoc with Rodolfo Llinas at the University of Iowa, and later joined the same department as a faculty member before the group

\footnotetext{
* Correspondence: hensbroek@hotmail.com

2Department of Neuroscience and Physiology, NYU Langone Health, 550 First Avenue, New York, NY 10016, USA

Full list of author information is available at the end of the article
}

permanently relocated to NYU. His research centered around single-cell neurophysiology of cerebellar neurons and their relation to the control of eye movements.

One of his first major contributions was the discovery that direction-specific retinal image slip modulates climbing fiber activity in the vestibulo-cerebellum [1,2]. These visual climbing fiber signals are believed to contribute to error feedback processing during adaptation of the vestibulo-ocular reflex, and thereby form a crucial component of the Marr - Albus - Ito hypothesis on cerebellar learning [3-5].

He then went on to establish that the accessory optic and vestibular systems are complementary detectors of self-motion that share a reference coordinate framework defined by head movements relative to space [6]. Building on this knowledge, he showed that retinal slip signals close the vestibulo-ocular reflex feedback loop using common, mutually orthogonal axes in three-dimensional space [7-10]. The notion that movement is coded in the brain using a common coordinate frame was consistent with the observation he and colleagues had made about the geometries of extraocular muscles and semicircular canals closely aligning with each other across species, be it lateral- or frontal-eyed [11]. Jerry further discovered that this reference frame had an anatomical counterpart in the modular organization of the vestibulo-cerebellum [12-14] and that topographic arrangements were preserved in the projections to the vestibular and cerebellar nuclei from these cerebellar microzones $[12,15]$.

He also made important contributions to our current understanding on the information content of climbing fibers [16]. Indeed, he was one of the first to show that visual climbing fibers in the flocculus can also signal non-visual information [17, 18]. Moreover, he showed that low-frequency climbing fiber input transmits graded signals to Purkinje cells in terms of the number of highfrequency spikelets [19], calling for a re-examination of the widely-held notion that climbing fiber input results in an all-or-none response in a Purkinje cell. 
The final stages of his career were primarily devoted to understanding the contribution of cortical interneurons in transforming mossy fiber activity to Purkinje cell output. He improved our insight into what unipolar brush cells, granule cells, Golgi cells, and molecular layer interneurons can encode during different forms of visual and vestibular stimulation [20-22].

Jerry was an extremely warm supervisor for many students and postdocs, taking care of minute details in person. Moreover, he was much interested in broadening opportunities for young investigators and donated generously to scientific organizations to fund scholarships and financial aid for meeting attendance.

Even though working had become physically taxing, Jerry remained an active scientist until a few months before his death and even managed to visit the last (2019) $\mathrm{SfN}$ meeting in Chicago, which he greatly enjoyed.

Jerry is buried in our blood and brain; he will be missed.

Chris De Zeeuw, Robert Hensbroek, Jun Maruta and Jan Voogd.

\section{Authors' contributions}

The authors contributed equally. The author(s) read and approved the final manuscript.

\section{Author details}

'Department of Neuroscience, Erasmus MC, Dr. Molenwaterplein 40, 3015 GE Rotterdam, The Netherlands. ${ }^{2}$ Department of Neuroscience and Physiology, NYU Langone Health, 550 First Avenue, New York, NY 10016, USA.

${ }^{3}$ Department of Neurology, Icahn School of Medicine at Mount Sinai, 1

Gustave L. Levy PI, New York, NY 10029, USA.

Published online: 04 May 2020

\section{References}

1. Maekawa K, Simpson JI. Climbing fiber responses evoked in vestibulocerebellum of rabbit from visual system. J Neurophysiol. 1973;36: 649-66.

2. Simpson Jl, Alley KE. Visual climbing fiber input to rabbit vestibulocerebellum: a source of direction-specific information. Brain Res. 1974;82: 302-8.

3. Marr D. A theory of cerebellar cortex. J Physiol. 1969:202:437-70

4. Albus JS. A theory of cerebellar function. Math Biosci. 1971;10:25-61.

5. Ito M. Neural design of the cerebellar motor control system. Brain Res. 1972; 40:81-4.

6. Simpson Jl. The accessory optic system. Annu Rev Neurosci. 1984;7:13-41.

7. Soodak RE, Simpson JI. The accessory optic system of rabbit. I. Basic visual response properties. J Neurophysiol. 1988;60:2037-54.

8. Simpson Jl, Leonard CS, Soodak RE. The accessory optic system of rabbit. II. Spatial organization of direction selectivity. J Neurophysiol. 1988;60:2055-72.

9. Leonard CS, Simpson Jl, Graf W. Spatial organization of visual messages of the rabbit's cerebellar flocculus. I. Typology of inferior olive neurons of the dorsal cap of Kooy. J Neurophysiol. 1988:60:2073-90.

10. Graf W, Simpson JI, Leonard CS. Spatial organization of visual messages of the rabbit's cerebellar flocculus. II. Complex and simple spike responses of Purkinje cells. J Neurophysiol. 1988;60:2091-121.

11. Simpson Jl, Graf W. Eye-muscle geometry and compensatory eye movements in lateral-eyed and frontal-eyed animals. Ann N Y Acad Sci. 1981;374:20-30

12. De Zeeuw Cl, Wylie DR, Digiorgi PL, Simpson Jl. Projections of individual purkinje cells of identified zones in the flocculus to the vestibular and cerebellar nuclei in the rabbit. J Comp Neurol. 1994;349:428-47.

13. Van der Steen J, Simpson JI, Tan J. Functional and anatomic organization of three-dimensional eye movements in rabbit cerebellar flocculus. J Neurophysiol. 1994;72:31-46.
14. Tan J, Gerrits NM, Nanhoe R, Simpson JI, Voogd J. Zonal organization of the climbing fiber projection to the flocculus and nodulus of the rabbit: $a$ combined axonal tracing and acetylcholinesterase histochemical study. J Comp Neurol. 1995:356:23-50.

15. Wylie DR, De Zeeuw Cl, Digiorgi PL, Simpson Jl. Projections of individual purkinje cells of identified zones in the ventral nodulus to the vestibular and cerebellar nuclei in the rabbit. J Comp Neurol. 1994;349:448-63.

16. Simpson Jl, Wylie DR, De Zeeuw Cl. On climbing fiber signals and their consequence(s). Behav Brain Sci. 1996;19:384-98.

17. De Zeeuw Cl, Wylie DR, Stahl JS, Simpson JI. Phase relations of Purkinje cells in the rabbit flocculus during compensatory eye movements. J Neurophysiol. 1995;74:2051-64

18. Winkelman BHJ, Belton T, Suh M, Coesmans M, Morpurgo MM, Simpson JI. Nonvisual complex spike signals in the rabbit cerebellar flocculus. J Neurosci. 2014:34:3218-30.

19. Maruta J, Hensbroek RA, Simpson Jl. Intraburst and interburst signaling by climbing fibers. J Neurosci. 2007;27:11263-70.

20. Simpson JI, Hulscher HC, Sabel-Goedknegt E, Ruigrok TJH. Between in and out: linking morphology and physiology of cerebellar cortical interneurons. Prog Brain Res. 2005;148:329-40.

21. Ruigrok TJH, Hensbroek RA, Simpson JI. Spontaneous activity signatures of morphologically identified interneurons in the vestibulocerebellum. J Neurosci. 2011;31:712-24.

22. Hensbroek RA, Ruigrok TJH, van Beugen BJ, Maruta J, Simpson JI. Visuovestibular information processing by unipolar brush cells in the rabbit Flocculus. Cerebellum. 2015;14:578-83.

\section{Publisher's Note}

Springer Nature remains neutral with regard to jurisdictional claims in published maps and institutional affiliations.

Ready to submit your research? Choose BMC and benefit from:

- fast, convenient online submission

- thorough peer review by experienced researchers in your field

- rapid publication on acceptance

- support for research data, including large and complex data types

- gold Open Access which fosters wider collaboration and increased citations

- maximum visibility for your research: over $100 \mathrm{M}$ website views per year

At $\mathrm{BMC}$, research is always in progress.

Learn more biomedcentral.com/submissions 